http:/www.journals.zu.edu.eg/journalDisplay.aspx?Journalld=1\&queryType=Master

\title{
WATER QUALITY EVALUATION FOR SUPPLEMENTARY IRRIGATION of CROPS GROWN IN SHARKIA GOVERNORATE, EGYPT
}

\author{
Adly M. Abd Al-Hamid*, K.G. Soliman, A.E. Nasr-Alla and M. Abu-Hashim \\ Soil Sci. Dept., Fac. Agric., Zagazig Univ., Egypt
}

Received: 14/11/2016 ; Accepted: 04/12/2016

\begin{abstract}
Water scarcity may become a real challenge in Egypt in the near future. Samples of irrigation and drainage water were taken monthly from Belbais, El-Qalubia main drains, and ElIsmailia canal to assess water quality and suitability for irrigation purposes. Salinity of water ranged between 0.33 and $2.45 \mathrm{dsm}^{-1}$ and sodium adsorption ratio (SAR) ranged between 3.6 to 15.94. Ranges of heavy metals in $\mathrm{mgl}^{-1}$ were 1.02-6.9 for $\mathrm{Fe}, 0.05-0.49$ for $\mathrm{Mn}, 0.15-1.1$ for $\mathrm{Zn}, 0.005-0.2$ for $\mathrm{Cu}$, 0.004-0.8 for $\mathrm{Co}, 0.03-0.24$ for $\mathrm{Ni}, 0.001-0.7$ for $\mathrm{Cd}, 0.14-0.84$ for $\mathrm{B}, 0.41-5.7$ for $\mathrm{Pb}$, and 0.83-9.2 for $\mathrm{NO}_{3}$, with cases of possible high contents of heavy metals in El-Manzala lake. According to USDA (1954), water class of Belbais and El-Qalubia main drains, and El-Ismailia canal is $C_{3} S_{1}$ (high salinity, low sodicity). According to Gupta (1984) water class is $\mathrm{C}_{3} \mathrm{~S}_{3}$ (high salinity, high sodicity). For trace elements and heavy metals based on the recommended maxima of the US committee on water quality, there is no hazard for $\mathrm{Fe}, \mathrm{Zn}, \mathrm{Cu}, \mathrm{Pb}$, or $\mathrm{Ni}$, but $\mathrm{Cd}$ content exceeded the permissible limits of 0.01 to $0.05 \mathrm{mgl}^{-1}$. Manganese exceeded the limit for continuous use in water of Belbais and El-Qalubia main drains; cobalt exceeded the limit in continuous use, but may be used for only 20 years in heavy soils. Other assessments including SAR/ SCAR were also carried out.
\end{abstract}

Key words: water scarcity, irrigation, salinity, trace elements, heavy metals.

\section{INTRODUCTION}

Drainage waters could be a readily available source of water for irrigation. The Egyptian ministry of irrigation estimates the total annual discharge of drainage water in Egypt about 12 billion $\mathrm{m}^{3}$ /year (FAO, 2002). Most of it is presently disposed of in the Mediterranean Sea and the Northern lakes of Delta. An intensive expansion program for the reuse of drainage water in agriculture requires adequate, proper measures and precautions due to salinity and alkalinity problems of waters to avoid accumulation of salts in the long term of applications of these waters.

Ayers and Westcot (1976) presented guidelines for evaluating water quality based on concepts introduced by U.S. salinity Laboratory such as $\mathrm{pH}_{\mathrm{c}}$ and adjusted sodium adsorption ratio (SAR). Gupta (1979a) suggested that irrigation water may be classified under five classes based on salinity and sodicity hazard and boron. $\mathrm{pH}$ of some wastewaters did not vary widely from that of the Nile water, and ranged from 7.29, 7.4 and 7.40 in sewage waters to the industrial wastewaters (FAO, 2002). El-Sherbieny et al. (1998) showed that $50 \%$ of the agricultural drainage water had $\mathrm{pH}$ ranging from 7.6 to 8.4. Shaban (1998) stated that the $\mathrm{pH}$ of irrigation water varied between 8.22 and 9.00 , and that the most prevalent values of $\mathrm{pH}$ of Nile water, drainage water and sewage water were 8.33, 8.34 and 8.46, respectively. Srivastava et al. (1962) reported that using sewage water having $\mathrm{pH} 7.8$, EC $1.4 \mathrm{dSm}^{-1}, 104 \mathrm{mgl}^{-1} \mathrm{NO}_{3}$-N and SAR 7.5 proved most efficient in reclaiming saline sodic soils. Zein et al. (2002) studied heavy metal concentrations of $\mathrm{Pb}, \mathrm{Mn}, \mathrm{Zn}, \mathrm{Cd}, \mathrm{Ni}$ and $\mathrm{Cu}$ in the Nile water for two seasons and obtained averages of $0.03,0.011,0.10,0.004,0.021$ and

\footnotetext{
* Corresponding author: Tel. : +201140206252

E-mail address: eng_adlyamr@yahoo.com
} 
$0.022 \mathrm{mgl}^{-1}$, for each elements, respectively. However, in drainage water the respective obtained values were $0.5,0.19,0.19,0.02,4.95$ and $0.08 \mathrm{mgl}^{-1}$ in the first season and $0.73,0.27$, $0.18,0.030,3.47$ and $0.06 \mathrm{mgl}^{-1}$, respectively. Ibrahim (2004) found that many non-saline water showed a very wide range in their concentrations of heavy metals depending on variations in climate, geology and anthropogenic activities.

The present study aims at evaluating seasonal variations of drainage water in Sharkia Governorate for irrigation purposes.

\section{MATERIALS AND METHODS}

\section{Drainage Water Sampling}

Water samples were taken to represent three water sources, i.e., the end of Belbais drain (source 1), the end of EI-Qalyubia main drain (source 2), and El-Ismalia canal (source 3). The samples were taken monthly during April 2014 to March 2015. Figs. 1 and 2 show the locations of the sources. The water samples were filtered and subjected to chemical analyses (Table 1).

\section{Water Analyses}

EC, $\mathrm{pH}$, soluble cations $\left(\mathrm{Ca}^{2+}, \mathrm{Mg}^{2+}, \mathrm{Na}^{+}\right.$, and $\left.\mathrm{K}^{+}\right)$and anions $\left(\mathrm{CO}_{3}{ }^{2-}, \mathrm{HCO}_{3}^{-}, \mathrm{Cl}^{-}\right)$were determined adopting the methods of USDA (1954) with the sulphate being estimated by difference. Boron was determined by the curcumin method according to Jackson (1958). Heavy metals were measured using Atomic Absorption Spectrophotometer Perkin-Elmer, model 290B, Norwalk, C.T (Perkin Elmer 3300. Ammonium and nitrate were determined by the Kjeldahl method using magnesium oxideDevarda alloy catalyst (Chapman and Pratt, 1961).

\section{Quality Indices}

Using the above chemical analyses, the following quality indices were determined:

Salinity was measured in terms of electric conductivity (EC) measured as $\mathrm{dSm}^{-1}$. Soluble sodium percentage (SSP) was calculated as:

$$
\mathrm{SSP}=\frac{\mathrm{Na}}{\sum \text { Cations }} \times 100
$$

Where:

Ions are expressed as $\mathrm{mmol}_{\mathrm{c}} \mathrm{l}^{-1}$

Sodium adsorption ratio (SAR) was calculated as:

$$
\mathrm{SAR}=\frac{\mathrm{Na}^{+}}{\sqrt{\mathrm{Ca}^{++}+\mathrm{Mg}^{++} / 2}}
$$

Where:

Ions are expressed as $\mathrm{mmol}_{\mathrm{c}} \mathrm{l}^{-1} \ldots .$. (2)

Adjusted Sodium Adsorption Ratio (adj. SAR) calculated according to the following equation (Ayers and Westcot, 1976):

$$
\begin{aligned}
& \text { Adj. } \mathrm{SAR}=\mathrm{SAR}\left[1+\left(8.4-\mathrm{pH}_{\mathrm{c}}\right)\right] \ldots \ldots \ldots . \\
& \mathrm{pH}_{\mathrm{c}}=\left(\mathrm{PK}_{2}{ }_{2}-\mathrm{PK}_{\mathrm{c}}^{\prime}\right)+\mathrm{p}\left(\mathrm{Ca}^{2+}+\mathrm{Mg}^{2+}\right)+\mathrm{p}(\mathrm{Alk})
\end{aligned}
$$

Adjusted sodium hazard (adj. ${ }^{\mathrm{R}} \mathrm{Na}$ ) was as follows:

$$
\operatorname{Adj} .{ }^{\mathrm{R}} \mathrm{Na}=\frac{\mathrm{Na}^{+}}{\sqrt{\mathrm{Ca}_{\mathrm{x}}^{2+}+\mathrm{Mg}^{2+} / 2}}
$$

(Suarez, 1981) ........ (5)

Where:

$\mathrm{Ca}_{\mathrm{x}}$ value is modified according to the salinity of the water, its $\mathrm{HCO}_{3} / \mathrm{Ca}$ ratio and the estimated partial pressure of $\mathrm{CO}_{2}$ in the surface few millimeters of soil $\left(\mathrm{PCO}_{2}=0.0007\right.$ atmospheres), and $\mathrm{Mg}$ in the water. The $\mathrm{Ca}_{\mathrm{x}}$, value represents the $\mathrm{Ca}$ that is expected to remain in solution in the soil water at equilibrium. The obtained adj. ${ }^{\mathrm{R}}$ $\mathrm{Na}$ is used in place of the SAR to evaluate the potential $\mathrm{Na}$ hazard which can cause an infiltration problems if used for irrigation.

Estimated exchangeable sodium percent (ESP) expected in the soil using the SAR of water, this equation was as follows (USDA, 1954).

$$
\mathrm{ESP}=\frac{100(-0.0126+0.001745 \mathrm{SAR})}{1+(-0.0126+0.001745 \mathrm{SAR})} \ldots . .(6)
$$

The Permeability Index (PI) was calculated as follows (Doneen, 1964):

$$
\mathrm{PI}=\frac{\mathrm{Na}^{+}+\sqrt{\mathrm{HCO}_{3}^{-}}}{\mathrm{Na}^{+}+\mathrm{Ca}^{2+}+\mathrm{Mg}^{2+}} \times 100
$$




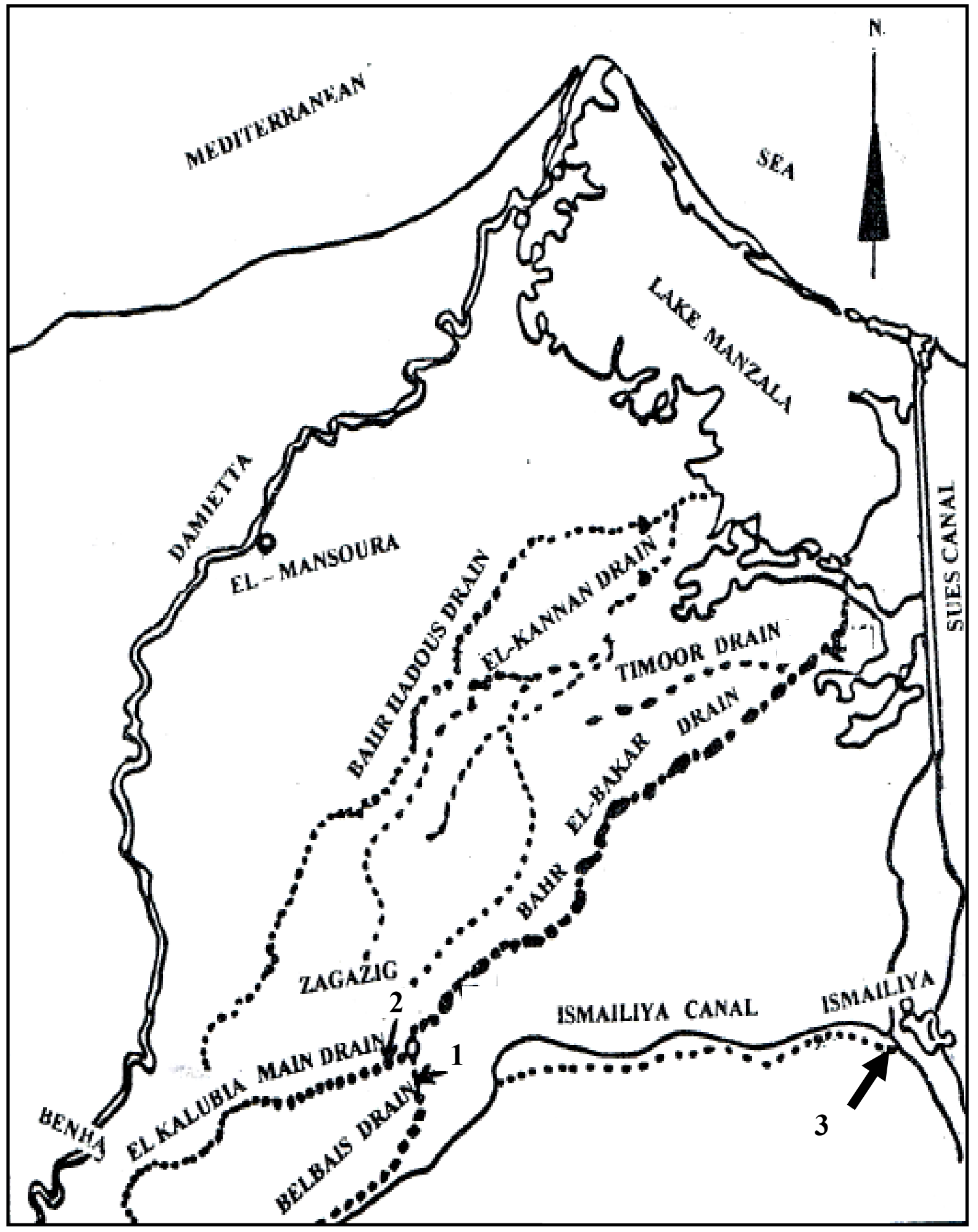

Fig. 1. The 3 locations of drainage water sampling taken from drains of Belbais, El-Qalubia drains and Ismailiya canal. Sharkia Governorate 


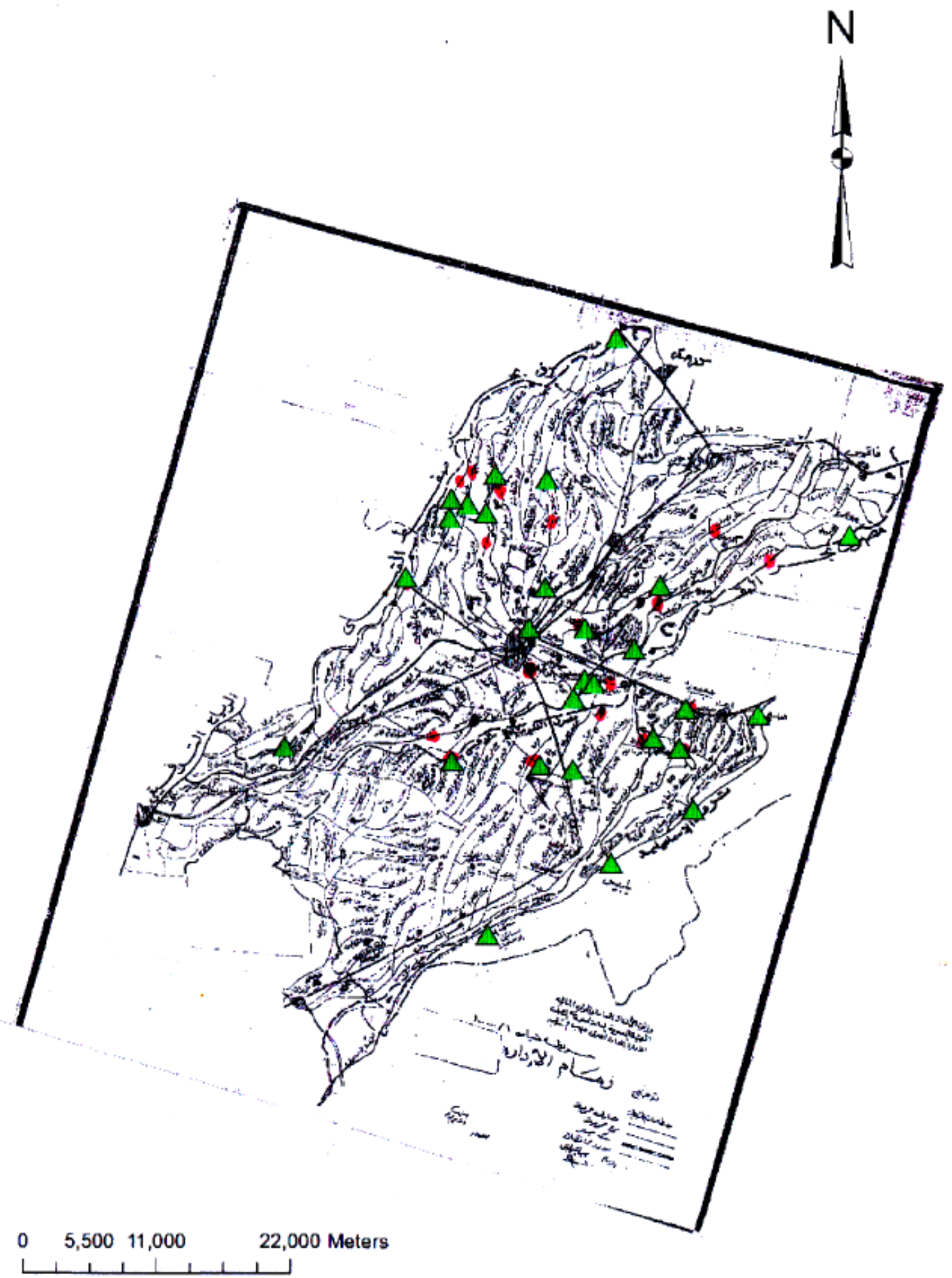

Fig. 2. Locations of the three water sources 


\section{RESULTS AND DISCUSSION}

Water quality was evaluated on basis of salinity, sodicity, residual sodium carbonate, boron, heavy metals and nitrogen. Tables 1, 2 and 3 show the chemical analyses of water samples from the 3 sources of Belbais, ElQalubia main drains, and El-Ismailia canal taken during April 2014 to March 2015. Lands where the two drains run through range from highly productive Nile alluvia to saline lacustrine soils. Thus water characteristics of drains would be affected by the nature, composition and salinity of soils from which the water were drained. Also lakes, sea and human activities would affect the properties of water of the drains drainage waters. All locations where water samples were taken are in the eastern part of Nile Delta.

\section{pH}

The $\mathrm{pH}$ values show that waters were slightly alkaline in all the studied drains and ranged between 7.1 to 8.3 such values are within the normal range of the FAO Guidelines for water quality (Ayers and Westcot, 1976).

\section{Salinity}

Classification of irrigation water with respect to salinity hazard is based primarily on the possible development of salinity in soil to the extent that yields are adversely affected. Drainage water analysis of the present study shows that water had below $2 \mathrm{dSm}^{-1}$ and salinity was lower in the summer than in the winter and the highest values occurred in February, due to holding back of Nile irrigation water during the winter closer period in January to February, in addition to the use of large quantities of Nile water for irrigation of summer crops particularly rice. The mean values of EC for the three water sources of 1(Belbais drain), 2 (El-Qaliobia drain) and 3 (Ismailia canal) were 1;57, 1.54 and $0.34 \mathrm{dSm}^{-1}$, respectively. Based on the classification of the U.S. Salinity laboratory staff (USDA, 1954), the water of sources 1 and 2 could be classified as class $\mathrm{C}_{3}$ (high salinity water with EC between 0.75 and 2.25 $\mathrm{dSm}^{-1}$, whereas water of source 3 could be classified as class $2\left(0.25-0.75 \mathrm{dSm}^{-1}\right)$. Based on the FAO Guidelines (Ayers and Westcot
1976) the water could be classified as class two " $\mathrm{C}_{2}$ " (less than $0.75 \mathrm{dSm}^{-1}$ ), which indicates increasing problems, whereas water of source 3 was class 1 "(less than $0.75 \mathrm{dSm}^{-1}$ ).

\section{Sodicity}

The parameter of "sodium adsorption ratio" (SAR) proposed by the USDA (1954), the waters range from no-sodicity hazard to sodicity hazard annual mean values for water were between 3.21 and 14.72, high during the winter and low during the summer. The high value indicates a sodicity hazard.

Regarding the parameter of Adjusted sodium hazard $\left(\operatorname{adj} .{ }^{\mathrm{R}} \mathrm{Na}\right)$ proposed by Gupta (1979a), values ranged between 1.30 and 12.09 indicating low to high sodium hazards.

\section{Chlorides and Bicarbonates}

Chlorides ranged between 0.18 and 2.85 mmolcL ${ }^{-1}$ indicating classes ranging from no problem to increasing problems according to the FAO Guidelines (Ayers and Westcot, 1976). The waters of the Qalubia and Belbais drains had higher values than water of Ismailia canal. Also according to FAO Guidelines, values of $\mathrm{HCO}_{3}$ ranged between 0.01 and 0.95 which indicating no problem. Water of the two drains showed higher values than water of Ismailia canal. On the other hand the $\mathrm{pHc}$ values of the water sources ranged from 8.8 to 8.9 (below 9.0 ), indicating the ability to precipitate soluble calcium.

\section{Soluble mineral $\mathrm{NO}_{3}-\mathrm{N}$}

The values of $\mathrm{NO}_{3}-\mathrm{N}$ ranged from 0.9 to 9.7 $\mathrm{mgl}^{-1}$. waters of the two drains had high values 5.3 to $9.7 \mathrm{mgl}^{-1}$. Whereas water of the two drains indicating no-problem and increasing problems. Ismailia canal had low values of 0.8 to $0.9 \mathrm{mgl}^{-1}$, indicating no problem class., these results are similar to those reported by El-Sherbieny et al. (1998), Abdel-Hamid et al. (2000), Soliman (2000) and Alnaimy et al. (2012).

\section{Boron}

Boron ranged from 0.14 to $0.34 \mathrm{mgl}^{-1}$ indicating low in Ismailia canal and relatively high in the two drains. However, contains in the three samples were of no B hazards (Branson et al.,1975; Soliman, 1983; Gupta, 1979b). These water can thus be used for most crops in most soils. 
Table 1. Mean values of dominant elements, some calculated indices, and classification for water samples collected from Belbais drain during April 2014 to March 2015

\begin{tabular}{|c|c|c|c|c|c|c|c|c|c|c|c|c|c|c|c|c|c|}
\hline \multirow[t]{2}{*}{ Month } & pH EC, Cations, mmolc $\mathrm{I}^{-1}$ & \multicolumn{9}{|c|}{ Anions, mmolc $\mathrm{I}^{-1}$} & \multicolumn{7}{|c|}{ Reusult } \\
\hline & $\mathrm{m}^{-1} \overline{\mathrm{Ca}^{2+} \mathrm{Mg}^{2+} \mathrm{Na}^{+} \mathrm{K}^{+}}$ & $\mathrm{CO}_{3}{ }^{=}$ & $\mathrm{HCO}_{3}^{-}$ & $\mathrm{Cl}^{-}$ & $\mathrm{SO}_{4}{ }^{=}$ & SSP & SAR RSC RSBC & PI & ESP & $\mathbf{p H}_{\mathrm{C}}$ & $\begin{array}{c}\text { Adj.S } \\
\text { AR }\end{array}$ & $\begin{array}{c}\text { Adj. }^{\mathrm{R}} \\
\mathbf{N a}\end{array}$ & SCAR & $\begin{array}{l}\text { SAR/ } \\
\text { SCAR }\end{array}$ & $\begin{array}{l}\text { RSC/ } \\
\text { RSBC }\end{array}$ & ICAR USDA & $\begin{array}{l}\text { USSL } \\
\text { Class }\end{array}$ \\
\hline Apr.20 & 47.801 .361 .671 .5412 .062 .09 & 0.00 & 0.69 & 1.65 & 15.02 & 69.47 & $9.52-2.52-0.98$ & 84.42 & 12.86 & 8.32 & & 4.95 & 9.33 & 1.02 & 2.57 & $\mathrm{C}_{3} \mathrm{~S}_{4}$ & \\
\hline Iay & 8.311 .401 .651 .5611 .521 .70 & 0.00 & 0.78 & 1.25 & 14.40 & 70.12 & $9.09-2.43-0.87$ & 84.20 & 12.23 & 8.22 & 10.73 & 5.37 & 8.97 & 1.01 & 2.79 & $\mathrm{C}_{3} \mathrm{~S}_{3}$ & Acceptable \\
\hline in. & 7.801 .751 .431 .3416 .001 .35 & 0.00 & 0.87 & 1.30 & 17.95 & 79.52 & $13.60-1.90-0.56$ & 90.21 & 18.91 & 8.20 & 16.31 & 12.09 & 13.38 & 1.02 & 3.39 & $\mathrm{C}_{2} \mathrm{~S}_{5}$ & Poor \\
\hline ul. & 7.801 .681 .871 .2313 .172 .91 & 0.00 & 0.91 & 1.70 & 16.57 & 68.66 & $10.57-2.19-0.96$ & 86.81 & 14.43 & 8.04 & 14.38 & 4.50 & 9.63 & 1.10 & 2.28 & $\mathrm{C}_{3} \mathrm{~S}_{4}$ & Poor \\
\hline Aug. & 7.501 .901 .451 .6515 .542 .50 & 0.00 & 0.86 & 1.30 & 18.98 & 73.51 & $12.48-2.24-0.59$ & 88.34 & 17.26 & 8.14 & 15.73 & 10.54 & - 12.90 & 0.97 & 3.80 & $\mathrm{C}_{3} \mathrm{~S}_{4}$ & Poor \\
\hline Sep. & 7.801 .861 .321 .2116 .561 .22 & 0.00 & 0.69 & 1.15 & 18.47 & 81.53 & $14.72-1.84-0.63$ & 91.10 & 20.58 & 8.34 & 15.60 & 11.84 & 14.41 & 1.02 & 2.92 & $\mathrm{C}_{3} \mathrm{~S}_{4}$ & Poor \\
\hline Oct. & 8.261 .591 .981 .3413 .971 .50 & 0.00 & 0.90 & 1.60 & 16.29 & 74.35 & $10.85-2.42-1.08$ & 86.29 & 14.83 & 8.06 & 14.53 & 11.75 & 9.93 & 1.09 & 2.24 & $\mathrm{C}_{3} \mathrm{~S}_{4}$ & Poor \\
\hline Nov. & 8.321 .601 .561 .3812 .772 .51 & 0.00 & 0.88 & 1.86 & 15.48 & 70.08 & $10.53-2.06-0.68$ & 87.25 & 14.36 & 8.12 & 13.48 & 9.59 & 10.22 & 1.03 & 3.03 & $\mathrm{C}_{2} \mathrm{~S}_{3} \quad \mathrm{C}_{3} \mathrm{~S}_{4}$ & Poor \\
\hline Dec. & 8.081 .732 .011 .6712 .731 .69 & 0.00 & 0.72 & 1.25 & 16.13 & 70.33 & $9.38-2.96-1.29$ & 82.75 & 12.66 & 8.11 & 12.11 & 4.29 & 8.98 & 1.05 & 2.29 & $\mathrm{C}_{2} \mathrm{~S}_{3} \quad \mathrm{C}_{3} \mathrm{~S}_{4}$ & Poor \\
\hline an.2015 & 57.901 .671 .981 .5510 .201 .95 & 0.00 & 0.92 & 1.15 & 13.61 & 65.05 & $7.68-2.61-1.06$ & 81.28 & 10.13 & 8.13 & 9.75 & 5.94 & 7.25 & 1.06 & 2.46 & $\mathrm{C}_{1} \mathrm{~S}_{3}$ & Poor \\
\hline Mar. & 8.121 .992 .121 .884 .543 .67 & 0.00 & 0.97 & 1.90 & 9.34 & 37.16 & $3.21-3.03-1.15$ & 64.67 & 3.49 & 8.00 & 4.49 & 3.74 & 3.11 & 1.03 & 2.63 & $\mathrm{C}_{2} \mathrm{~S}_{3}$ & Acceptable \\
\hline Average & 7.301 .571 .591 .3711 .412 .06 & 0.00 & 0.77 & 1.32 & 14.34 & 62.48 & $9.15-2.19-0.82$ & 77.08 & 12.42 & 7.47 & 11.25 & 6.60 & 8.88 & 0.95 & 2.55 & & \\
\hline \multicolumn{18}{|c|}{$\begin{array}{l}\text { - Water quality class according to USDA (1954); } \mathrm{C}_{1}, \mathrm{C}_{2}, \mathrm{C}_{3}, \mathrm{C}_{4} \text { are low, medium, high and very high salinity; } \mathrm{S}_{1}, \mathrm{~S}_{2}, \mathrm{~S}_{3}, \mathrm{~S}_{4} \text { are low, medium, high and very high } \\
\text { sodicity respectively. }\end{array}$} \\
\hline \multicolumn{18}{|c|}{ • SCAR : Sodium, calcium activity ratio $=\mathrm{Na} / \sqrt{ } \mathrm{Ca}$. in me $/ 1$ (Gupta 1984). } \\
\hline \multicolumn{18}{|c|}{$\begin{array}{l}\cdots \text { ICAR water quality class according to Gupta }(1979 \mathrm{a} ; \mathrm{b}) ; \mathrm{C}_{0}, \mathrm{C}_{1}, \mathrm{C}_{2}, \mathrm{C}_{3}, \mathrm{C}_{4}, \mathrm{C}_{5} \text { are non, normal, low, medium, high and very high salinity; } \mathrm{S}_{0}, \mathrm{~S}_{1}, \mathrm{~S}_{2}, \mathrm{~S}_{3}, \mathrm{~S}_{4}, \mathrm{~S}_{5} \\
\text { are non, normal, low, medium, high, and very high sodicity, respectively. }\end{array}$} \\
\hline
\end{tabular}


Table 2. Mean values of dominant elements, some calculated indices, and classification for water samples collected from El-Qalubia main drain during April 2014 to March 2015

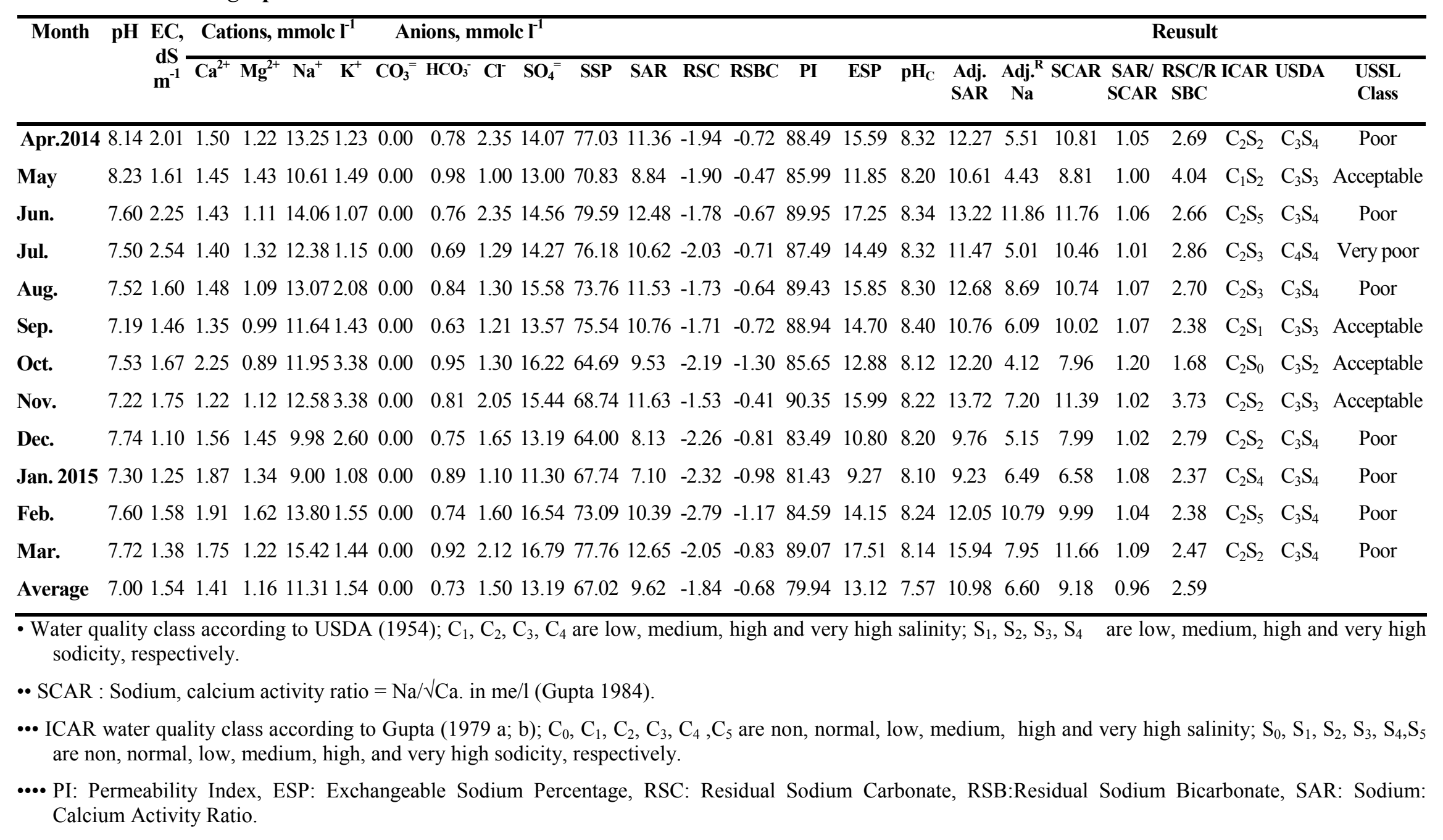


Table 3. Mean values of dominant elements, some calculated indices, and classification for water samples collected from El-Ismailia canal during April 2014 to March 2015

\begin{tabular}{|c|c|c|c|c|c|c|c|c|c|c|c|c|c|c|c|c|c|c|c|c|c|c|c|}
\hline \multirow[t]{2}{*}{ Season } & \multirow{2}{*}{\multicolumn{2}{|c|}{$\begin{array}{l}\text { pH EC, } \\
\mathrm{dSm}^{-1}\end{array}$}} & \multicolumn{4}{|c|}{ Cations, mmolc $\mathrm{I}^{-1}$} & \multicolumn{4}{|c|}{ Anions, mmolc $\mathrm{I}^{-1}$} & \multirow[b]{2}{*}{ SSP } & \multirow[b]{2}{*}{ SAR } & \multirow[b]{2}{*}{ RSC } & \multirow[b]{2}{*}{ RSBC } & \multirow[b]{2}{*}{ PI } & \multirow[b]{2}{*}{ ESP } & \multirow[b]{2}{*}{$\mathbf{p H}_{\mathrm{C}}$} & \multicolumn{6}{|c|}{ Reusult } \\
\hline & & & $\mathrm{Ca}^{2+}$ & $\mathbf{M g}^{2+}$ & $\mathrm{Na}^{+}$ & $\overline{\mathbf{K}^{+}}$ & $\mathrm{CO}_{3}{ }^{=}$ & $\mathrm{HCO}_{3}^{-}$ & $\mathrm{Cl}^{-}$ & $\mathrm{SO}_{4}{ }^{=}$ & & & & & & & & $\begin{array}{l}\text { Adj. } \\
\text { SAR }\end{array}$ & $\begin{array}{r}\text { Adj. }^{\mathrm{R}} \\
\mathbf{N a}\end{array}$ & SCAR & $\begin{array}{l}\text { SAR/ } \\
\text { SCAR }\end{array}$ & $\begin{array}{l}\text { RSC/ } \\
\text { RSBC }\end{array}$ & $\begin{array}{r}\text { ICAR USDA USSL } \\
\text { Class }\end{array}$ \\
\hline Summer & 7.50 & 0.35 & 0.60 & 0.59 & 3.61 & 1.30 & 0.00 & 0.65 & 0.55 & 4.90 & 59.18 & 4.68 & -0.54 & 0.05 & 97.50 & 5.68 & 8.61 & 3.70 & 1.54 & 4.66 & 1.00 & 10.80 & $\mathrm{C}_{1} \mathrm{~S}_{2} \quad \mathrm{C}_{2} \mathrm{~S}_{2}$ Good \\
\hline Autom & 7.35 & 0.33 & 0.62 & 0.57 & 3.49 & 1.12 & 0.00 & 0.49 & 0.28 & 4.92 & 60.17 & 4.52 & -0.70 & -0.13 & 97.02 & 5.44 & 8.60 & 3.62 & 1.30 & 4.43 & 1.02 & 5.38 & $\mathrm{C}_{1} \mathrm{~S}_{2} \quad \mathrm{C}_{2} \mathrm{~S}_{2}$ Good \\
\hline Winter & 7.43 & 0.34 & 0.56 & 0.55 & 3.55 & 1.21 & 0.00 & 0.53 & 0.41 & 4.91 & 60.48 & 4.77 & -0.58 & -0.03 & 97.30 & 5.80 & 8.62 & 3.72 & 1.41 & 4.74 & 1.00 & 19.33 & $\mathrm{C}_{1} \mathrm{~S}_{2} \quad \mathrm{C}_{2} \mathrm{~S}_{2}$ Good \\
\hline Spring & 7.23 & 0.33 & 0.51 & 0.50 & 3.40 & 1.11 & 0.00 & 0.56 & 0.18 & 4.76 & 61.59 & 4.78 & -0.45 & 0.05 & 102.21 & 5.83 & 8.61 & 3.78 & 2.57 & 4.76 & 1.00 & 9.00 & $\mathrm{C}_{1} \mathrm{~S}_{2} \quad \mathrm{C}_{2} \mathrm{~S}_{2}$ Good \\
\hline Average & 7.38 & 0.34 & 0.57 & 0.55 & 3.51 & 1.19 & 0.00 & 0.56 & 0.35 & 4.87 & 60.36 & 4.69 & -0.57 & -0.02 & 98.51 & 5.69 & 8.61 & 3.70 & 1.70 & 4.65 & 1.01 & 37.83 & \\
\hline
\end{tabular}

- Water quality class according to USDA (1954); $\mathrm{C}_{1}, \mathrm{C}_{2}, \mathrm{C}_{3}, \mathrm{C}_{4}$ are low, medium, high and very high salinity; $\mathrm{S}_{1}, \mathrm{~S}_{2}, \mathrm{~S}_{3}, \mathrm{~S}_{4}$ are low, medium, high and very high sodicity respectively.

•• SCAR : Sodium, Calcium activity ratio $=\mathrm{Na} / \sqrt{ } \mathrm{Ca}$. in me/l (Gupta 1984).

... ICAR water quality class according to Gupta (1979 a; b); $C_{0}, C_{1}, C_{2}, C_{3}, C_{4}, C_{5}$ are non, normal, low, medium, high and very high salinity; $S_{0}, S_{1}, S_{2}, S_{3}, S_{4}, S_{5}$ are non, normal, low, medium, high, and very high sodicity, respectively.

... PI: Permeability Index, ESP: Exchangeable Sodium Percentage, RSC: Residual Sodium Carbonate, RSB:Residual Sodium Bicarbonate, SAR: Sodium: Calcium Activity Ratio. 


\section{Micronutrients}

Data in Tables 4, 5 and 6 show that ranges of micro-nutrients and heavy metals were 1.026.9 for $\mathrm{Fe}, 0.15-1.1$ for $\mathrm{Zn}, 0.05-0.49$ for $\mathrm{Mn}$, 0.005- 0.2 for $\mathrm{Cu}, 0.004-0.08$ for $\mathrm{Co}, 0.03-$ 0.24 for $\mathrm{Ni}, 0.001-0.07$ for $\mathrm{Cd}, 0.14-0.84$ for $\mathrm{B}, 0.41-5.7$ for $\mathrm{Pb}$, and $0.83-9.2$ for Nitrate. These values are in agreement with Ramadan (1995) and Mohamed et al. (1999) on basis of US committee on water quality (Branson et al., 1975) waters of the three sources may be assessed as follows:

1. For $\mathrm{Fe}, \mathrm{Zn}, \mathrm{Cu}, \mathrm{pb}$ and $\mathrm{Ni}$ all waters of the 3 sources are within the maximum permissible limit whether used continuously or used for of up to 20 years on heavy soils.

2. For Cd: of the two drains exceeded permissible limit.

3. For Co : waters of the two drains could be within the permissible limit if used continuously on all soils; but below the limit if used for up to 20 years on fine textured soils of $\mathrm{pH} 6$ to 8.5 .
4. For Mn: waters of the two drains exceeded the permissible limit regarding continuous use. Regarding use for up to 20 years on fine textured soils, waters of the three sources have contents below the permissible limits.

Accumulation of heavy metals in soil, leads to their adsorption by soil colloids, such as clay minerals and iron and aluminium oxides. They may also form complexes with soil organic colloids as well as with the slightly soluble inorganic compounds such as hydroxides, hydrous oxides, carbonates and phosphates. Equilibria between metal ions and soil components may be considerably altered, if the heavy metal is in high contents. On the other hand, these metals can be leached into the ground water either in ionic forms or as soluble complexes with organic substances (Willems et al., 1981; Abdel-Aal et al., 1988). Ramadan (1995) reported that Manzala lake water near Bahr El Bakar drain showed average contents $\left(\mathrm{mgl}^{-1}\right)$ of $8.90,0.63,1.98,0.59,0.44,0.77,0.10$ and 5.90 for $\mathrm{Fe}, \mathrm{Zn}, \mathrm{Mn}, \mathrm{Cu}, \mathrm{Co}, \mathrm{Ni}, \mathrm{Cd}, \mathrm{Pb}$.

Table 4. Mean values of miscellaneous elements content for samples collected from Belbais drain during April 2014 to March 2015

\begin{tabular}{|c|c|c|c|c|c|c|c|c|c|c|}
\hline \multirow[t]{2}{*}{ Month } & \multicolumn{9}{|c|}{$\mathrm{mgl}^{-1}$} & \multirow[b]{2}{*}{ Nitrate-N } \\
\hline & B & $\mathrm{Fe}$ & Mn & $\mathrm{Zn}$ & $\mathrm{Cu}$ & Co. & $\mathbf{N i}$ & $\mathbf{C d}$ & $\mathbf{P b}$ & \\
\hline Apr.2014 & 0.44 & 5.60 & 0.39 & 1.03 & 0.14 & 0.08 & 0.09 & 0.02 & 3.80 & 7.10 \\
\hline May & 0.50 & 4.41 & 0.38 & 0.66 & 0.12 & 0.05 & 0.16 & 0.03 & 3.60 & 6.40 \\
\hline Jun. & 0.47 & 4.81 & 0.37 & 0.88 & 0.15 & 0.05 & 0.21 & 0.02 & 3.65 & 7.80 \\
\hline Jul. & 0.51 & 3.90 & 0.42 & 0.41 & 0.12 & 0.06 & 0.17 & 0.03 & 3.70 & 5.70 \\
\hline Aug. & 0.41 & 4.00 & 0.38 & 0.65 & 0.12 & 0.05 & 0.06 & 0.02 & 3.80 & 6.50 \\
\hline Sep. & 0.47 & 3.2 & 0.39 & 0.39 & 0.14 & 0.05 & 0.05 & 0.04 & 3.50 & 5.90 \\
\hline Oct. & 0.38 & 4.62 & 0.39 & 0.59 & 0.13 & 0.06 & 0.04 & 0.05 & 3.60 & 5.34 \\
\hline Nov. & 0.55 & 4.92 & 0.41 & 0.54 & 0.15 & 0.05 & 0.15 & 0.04 & 3.70 & 6.40 \\
\hline Dec. & 0.52 & 3.74 & 0.42 & 0.44 & 0.14 & 0.04 & 0.16 & 0.01 & 3.80 & 5.57 \\
\hline Jan. 2015 & 0.81 & 3.40 & 0.43 & 0.87 & 0.15 & 0.04 & 0.2 & 0.03 & 4.10 & 8.50 \\
\hline Feb. & 0.83 & 6.90 & 0.45 & 1.10 & 0.16 & 0.05 & 0.22 & 0.07 & 4.40 & 9.70 \\
\hline Mar. & 0.79 & 4.30 & 0.42 & 1.09 & 0.14 & 0.04 & 0.17 & 0.04 & 4.10 & 8.10 \\
\hline Average & 0.56 & 4.48 & 0.40 & 0.72 & 0.14 & 0.05 & 0.14 & 0.03 & 3.81 & 6.92 \\
\hline
\end{tabular}


Table 5. Mean values of miscellaneous elements content for samples collected from El-Qalubia main drain during April 2014 to March 2015

\begin{tabular}{|c|c|c|c|c|c|c|c|c|c|c|}
\hline \multirow[t]{2}{*}{ Month } & \multicolumn{9}{|c|}{$\mathrm{mgl}^{-1}$} & \multirow[b]{2}{*}{ Nitrate-N } \\
\hline & B & $\mathrm{Fe}$ & Mn & $\mathbf{Z n}$ & $\mathrm{Cu}$ & Co. & $\mathbf{N i}$ & Cd & $\mathbf{P b}$ & \\
\hline Apr.2014 & 0.84 & 5.80 & 0.42 & 0.88 & 0.15 & 0.06 & 0.15 & 0.02 & 4.65 & 7.70 \\
\hline May & 0.81 & 3.90 & 0.38 & 0.78 & 0.17 & 0.07 & 0.14 & 0.03 & 5.70 & 6.50 \\
\hline Jun. & 0.77 & 4.50 & 0.49 & 0.64 & 0.15 & 0.05 & 0.11 & 0.02 & 5.30 & 5.30 \\
\hline Jul. & 0.78 & 5.06 & 0.39 & 0.63 & 0.14 & 0.08 & 0.24 & 0.06 & 4.90 & 7.76 \\
\hline Aug. & 0.73 & 4.62 & 0.46 & 0.67 & 0.16 & 0.06 & 0.18 & 0.02 & 5.10 & 8.02 \\
\hline Sep. & 0.65 & 4.68 & 0.45 & 0.57 & 0.17 & 0.05 & 0.19 & 0.03 & 4.70 & 6.28 \\
\hline Oct. & 0.66 & 4.69 & 0.44 & 0.47 & 0.18 & 0.04 & 0.11 & 0.04 & 4.30 & 4.54 \\
\hline Nov. & 0.57 & 4.62 & 0.43 & 0.37 & 0.19 & 0.03 & 0.01 & 0.05 & 3.90 & 5.80 \\
\hline Dec. & 0.79 & 3.62 & 0.42 & 0.27 & 0.20 & 0.02 & 0.21 & 0.06 & 3.50 & 6.06 \\
\hline Jan. 2015 & 0.78 & 4.62 & 0.41 & 0.17 & 0.21 & 0.01 & 0.19 & 0.07 & 3.10 & 5.63 \\
\hline Feb. & 0.78 & 5.90 & 0.40 & 1.10 & 0.16 & 0.05 & 0.22 & 0.01 & 3.50 & 9.20 \\
\hline Mar. & 0.71 & 5.10 & 0.39 & 1.09 & 0.14 & 0.04 & 0.18 & 0.02 & 3.70 & 7.90 \\
\hline Average & 0.74 & 4.76 & 0.42 & 0.64 & 0.17 & 0.05 & 0.16 & 0.04 & 4.36 & 6.72 \\
\hline
\end{tabular}

Table 6. Mean values of miscellaneous elements content for samples collected from EI-Ismailia canal during April 2014 to March 2015

\begin{tabular}{lcccccccccc}
\hline Season & \multicolumn{10}{c}{. $^{-1}$} \\
\cline { 2 - 11 } & $\mathbf{B}$ & $\mathbf{F e}$ & $\mathbf{M n}$ & $\mathbf{Z n}$ & $\mathbf{C u}$ & $\mathbf{C o .}$ & $\mathbf{N i}$ & $\mathbf{C d}$ & $\mathbf{P b}$ & Nitrate-N \\
\hline Summer & 0.154 & 1.891 & 0.053 & 0.162 & 0.005 & 0.005 & 0.031 & 0.003 & 0.413 & 0.863 \\
Autom & 0.173 & 1.021 & 0.072 & 0.192 & 0.005 & 0.005 & 0.221 & 0.001 & 0.554 & 0.842 \\
Winter & 0.163 & 2.131 & 0.074 & 0.221 & 0.009 & 0.004 & 0.171 & 0.002 & 0.672 & 0.911 \\
Spring & 0.144 & 2.432 & 0.064 & 0.152 & 0.006 & 0.004 & 0.031 & 0.003 & 0.412 & 0.832 \\
Average & 0.162 & 1.872 & 0.064 & 0.184 & 0.010 & 0.005 & 0.112 & 0.002 & 0.514 & 0.862 \\
\hline
\end{tabular}


Conclusive Assessment on Suitablility of Waters for Irrigation

The obtained data show that the two drainage waters were classified as class $\mathrm{C}_{3} \mathrm{~S}_{4}$ i.e., of high salinity high sodicity hazards according to the classification of the US Salinity Laboratory (USDA 1954), Water of Ismailia canal was $\mathrm{C}_{2} \mathrm{~S}_{2}$ i.e., medium salinity, medium sodicity. The waters of the drains can be used with care for crops which are tolerant to salinity such as cotton and barley. Also, they may be used for irrigation of crops grown on coarse textured soils with less hazards than those grown on fine textured ones. According to Gupta's classification, waters would be classified as follows:

(1) Water of El-Qalubia drain: $\mathrm{A}_{1} \mathrm{~B}_{1} \mathrm{C}_{1}$ (i.e. normal water with regard to sodicity, boron and salinity).

(2) Water of Belbais drain: $\mathrm{A}_{1} \mathrm{~B}_{1} \mathrm{C}_{1}$ (i.e. normal with regard to sodicity and boron, but with low salinity hazards).

(3) Water of Isamilia canal: $\mathrm{A}_{1} \mathrm{~B}_{1} \mathrm{C}_{1}$ (i.e. normal water with regard to sodicity, boron and salinity).

App. 1. The FAO guidelines for interpretation of water quality for irrigation according to Ayers and Westcot (1976)

\begin{tabular}{|c|c|c|c|}
\hline \multirow[t]{2}{*}{ Irrigation problems } & \multicolumn{3}{|c|}{ Degree of problem } \\
\hline & $\begin{array}{c}\text { No. } \\
\text { problem }\end{array}$ & $\begin{array}{c}\text { Increasing } \\
\text { problem }\end{array}$ & $\begin{array}{c}\text { Severe } \\
\text { problem }\end{array}$ \\
\hline Salinity (affects crops water availability) $\mathrm{EC}_{\mathrm{W}}\left(\mathrm{dSm}^{-1}\right)$ & $<0.75$ & $0.75-3.0$ & $>3.0$ \\
\hline \multicolumn{4}{|l|}{ Permeability (affects infiltration rate into soil) $\mathrm{EC}_{\mathrm{W}}\left(\mathrm{dSm}^{-1}\right)$} \\
\hline Adj.SAR & $>0.5$ & $0.5-0.2$ & $<0.2$ \\
\hline Montmorillonite (2:1 crystal lattice) & $>6$ & $6-9$ & $>9$ \\
\hline Illite-Vermicultic ( $2: 1$ crystal lattice) & $<8$ & $8-16$ & $>16$ \\
\hline Kaolinite-sesquioxides (1:1 crystal lattice) & $<16$ & $16-22$ & $>22$ \\
\hline \multicolumn{4}{|l|}{ Specific ion Toxicity (affects sensitive crops) } \\
\hline Sodium / (adj.SAR) & $<3$ & $3-9$ & $>9$ \\
\hline Chloride (meq $\mathrm{l}^{-1}$ ) & $<4$ & $4-10$ & $>10$ \\
\hline Boron $\left(\mathrm{mgl}^{-1}\right)$ & $<0.75$ & $0.75-2.0$ & $>2.0$ \\
\hline \multicolumn{4}{|l|}{ Miscellaneous effects (affects susceptible crops) } \\
\hline $\mathrm{NO}_{3}-\mathrm{N}($ or $) \mathrm{NH}_{4}-\mathrm{N}\left(\mathrm{mel}^{-1}\right)$ & $<5$ & $5-30$ & $>30$ \\
\hline $\mathrm{HCO}_{3}\left(\right.$ meql $\left.^{-1}\right)($ overhead sprinkling) & $<1.5$ & $1.5-8.5$ & $<8.5$ \\
\hline pH & \multicolumn{3}{|c|}{ Normal range(6.8-8.4) } \\
\hline
\end{tabular}

App. 2. USDA classification of irrigation water

\begin{tabular}{lccccc}
\hline Salinity hazard & Class & $\mathbf{E C}\left(\mathbf{d S m}^{-1}\right)$ & Sodicity hazard & Class & SAR \\
\hline Low & $\mathrm{C} 1$ & $0.1-0.25$ & Low & S1 & $10<$ \\
Medium & $\mathrm{C} 2$ & $0.25-0.75$ & Medium & $\mathrm{S} 2$ & $10-18$ \\
High & $\mathrm{C} 3$ & $0.75-2.25$ & High & $\mathrm{S} 3$ & $18-26$ \\
Very high & $\mathrm{C} 4$ & $2.25-5.00$ & Very high & S4 & $>26$ \\
\hline
\end{tabular}


App. 3. Gupta's ABC classification of irrigation water (Gupta, 1979b)

\begin{tabular}{lccccc}
\hline Class & Adj. SAR & Class & Boron $\left(\mathbf{m g l}^{\mathbf{1}}\right)$ & Class & EC dSm $^{-1}$ \\
\hline $\mathrm{A}_{1}$ & $<10$ & $\mathrm{~B}_{1}$ & $<3$ & $\mathrm{C}_{1}$ & $<1.5$ \\
$\mathrm{~A}_{2}$ & $10-20$ & $\mathrm{~B}_{2}$ & $3-4$ & $\mathrm{C}_{2}$ & $1.5-3$ \\
$\mathrm{~A}_{3}$ & $20-30$ & $\mathrm{~B}_{3}$ & $4-5$ & $\mathrm{C}_{3}$ & $3-5$ \\
$\mathrm{~A}_{4}$ & $30-40$ & $\mathrm{~B}_{4}$ & $5-10$ & $\mathrm{C}_{4}$ & $5-10$ \\
$\mathrm{~A}_{5}$ & $<40$ & $\mathrm{~B}_{5}$ & $<10$ & $\mathrm{C}_{5}$ & $>10$ \\
\hline
\end{tabular}

App. 4. Maximum concentrations of trace elements in irrigation waters, recommended by the US committee on water quality"

\begin{tabular}{lcc}
\hline Element (symbol) & $\begin{array}{c}\text { For waters used } \\
\text { continuously on all } \\
\text { soils }\end{array}$ & $\begin{array}{c}\text { For use up to 20 years on } \\
\text { fine Textured soils of pH } \\
\text { (6.0 to 8.5 }\end{array}$ \\
\cline { 2 - 3 } $\mathbf{~ m g l}^{-1}$ & mgl $^{-1}$ \\
\hline Aluminum (AI) & 5.00 & 20.0 \\
Arsenic (AS) & 0.10 & 2.0 \\
Beryllium (Be) & 0.10 & 0.5 \\
Boron (B) & 0.75 & 2.0 \\
Cadmium (Cd) & 0.01 & 0.05 \\
Chromium (Cr) & 0.10 & 1.0 \\
Cobalt (Co) & 0.05 & 5.0 \\
Copper (Cu) & 0.20 & 5.0 \\
Fluoride (F) & 1.00 & 15.0 \\
Iron (Fe) & 5.00 & 20.0 \\
Lead (Pb) & 5.00 & 10.0 \\
Lithium (Li) & 2.50 & 2.50 \\
Manganese (Mn) & 0.20 & 2.0 \\
Molybdenum (Mo) & 0.01 & 0.05 \\
Nickel (Ni) & 0.20 & 2.0 \\
Selenium (Se) & 0.02 & 0.02 \\
Vanadium (V) & 0.10 & 1.0 \\
Zinc (Zn) & 2.00 & 10.0 \\
\hline & & \\
\hline
\end{tabular}

*These levels will normally not adversely affect plants or soils.No data available for Mercury (Hg),Silver (Ag),Tin (Sn), Titanium (Ti), Tungsten (W).

$=$ Recommend maximum concentration for citrus is $0.75 \mathrm{mgl}-1$.

+ Only for acid fine textured soils or acid soils with relatively high iron oxids contents.

(Cited from Branson et al., 1975) 


\section{REFERENCES}

Abdel-Aal, Sh.I., R.R. Shahin, M.A. AbdelHamid and M.M. Abdel-Tawab (1988). Impact of liquid wastes of indaustrial complex at Helwan on water quality of both Nile and Canal streams. Egypt. J. Soil. Sci., 28 (4): $421-432$.

Abdel-Hamid, M.W., A.E. Nasr-Alla and K.G. Soliman (2000). Evaluation the quality of irrigation and drainage waters contributing to EL-Salam canal, Egypt J. Appl. Sci., 15 (3): 325-345.

Alnaimy, M.A., K.G. Soliman, N.A. Atia and E.A. El-Naka (2012). Spatial and temporal evaluation of El-Salam canal water resources for irrigation purposes. Zagazig J. Agric. Res., $39: 5$.

Ayers, R.S. and D.W. Westcot (1976). Water Quality for Agriculture, FAO Irrigation and Drainage, paper, No. 29, FAa Rome, Italy.

Branson, R.L., P.F. Pratt, J.D. Rhoades and J.D. Oster (1975). Water Quality in Irrigation Water Sheds. J. Environ. Quality, 4 : 33-40.

Chapman, H.D. and P.F. Pratt (1961). Methods of Analysis for Soil, Plant and Water. Div. Agric. Sci., Calif. Univ., Berkley.

Doneen, L.D. (1964). Notes on Water Quality in Agriculture. Water Science and Engineering paper No. 4001. Dept. of Water Sci. and Eng., Calif. Univ., USA.

El-Sherbieny, A.E., S.A. El-Saadany and F.A.A. Osman (1998). Seasonal variations in quality of some drainage water in Sharkia Governorate. Egypt. J. Soil Sci., 38 (1-4): 185-198.

FAO (2002). Food and Agriculture Organization, FAO year book, preduction, 55, FAO, Rome, Italy, $16: 4-6$.

Gupta, I.C. (1979a). Use of Saline Water in Agriculture in Arid and Semi-arid zones of India. Oxford and IBH Publishing Co., Pvt. Ltd., New Delhi, India.

Gupta, I.C. (1979b). Note on the effect of leaching and gypsum on the detoxication of boron in saline-sodic soils. Curr. Agric., 4 : 51- 55.

Gupta, L.C. (1984). Reassessment of irrigation water quality criteria and standards. Curr. Agric., 8 : 113-126.
Ibrahim, M.S. (2004). Effect of farm practices on soils of east Nile Delta. M.Sc. Thesis, Fac. Agric., Ain Shams Univ., Egypt.

Jackson, M.L. (1958). Soils Chemical Analysis, Prentice. Hall Inc., Englewood Cliffs, New Jersey, USA.

Mohamed, L.R., A.E. Nasr-Alla and W.M. Mosad (1999). Evaluation drainage water quality in El-Garbia Governorate. Egypt. J. Appl. Sci., 14 (7): 295- 308.

Ramadan, S.A. (1995). Heavy metals pollution in Manzala lake and the possibility of its water re-use. J. Agric. Sci. Mansoura Univ., 20 (10): 4501 - 4513.

Shaban, Kh.A.H. (1998). Studies on pollution of some cultivated soils. M.Sc. Thesis, Fac. Agric., Zagazig Univ., Egypt.

Soliman, K.G. (1983). Evaluation of drainage water as additional resources for irigation in Sharkia Governorate. M.Sc. Thesis, Fac. Agric., Zagazig Univ., Egypt.

Soliman, K.G. (2000). Assessing pollution and quality of Bahr El-Bakar drain-system waters for salinity, sodicity and heavy metals and possibility of ru-use in irrigation. Egypt. J. App. Sci., 15 (2): 301-328.

Srivastava, P.B.L., C.L. Mehrotra and R.R. Agarwal (1962). The effect of leaching saline alkali soil with irrigation waters of different kinds on the permeability and the composition of the soils and composition of the leachates. J. Indian Soc. Soil Sci., 10 : 93-96.

Suarez, D.L. (1981). Relationship between pH and SAR and an alternative method for estimating SAR of soil or drainage water. Soil Sci. Soc. Ame. J., 45 : 469 - 75.

USDA (1954). Diagnosis and Improvement of Saline and Alkali Soils. United State Agric. Dept., (USDA) Hand book 60.

Willems, M., B. Pedersen and J.S. Storgaar (1981). Accelerated leaching of some common and trace element from soil mixed with sewage sludge or sludge ash. Acta Agric.Scand., $31: 23-342$.

Zein, F.I., M.Z. Abou Amou, A.A. El-Leithy and M.M. El-Shami (2002). Effect of polluted irrigation water on some crops and their contents of heavy metals. 1. Wheat. Egypt. J. Soil Sci., 42 (1): 139- 159. 


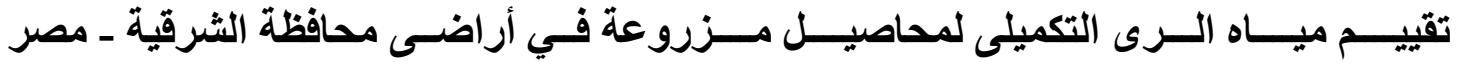

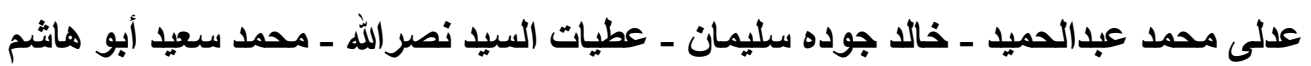

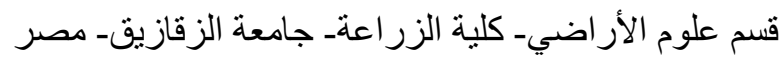

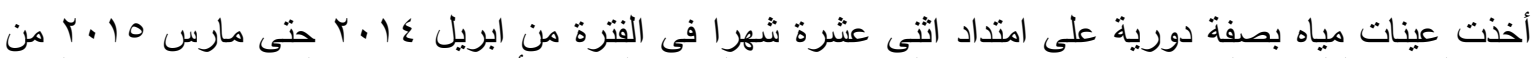

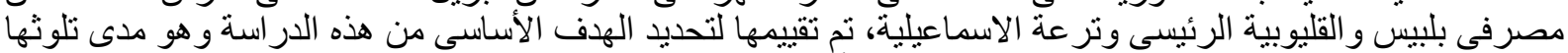

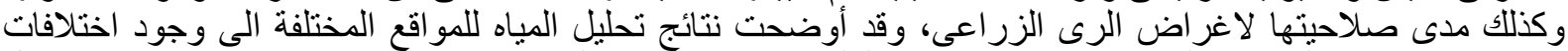

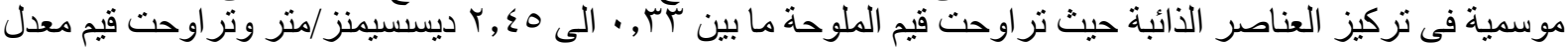

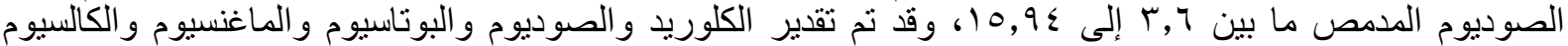

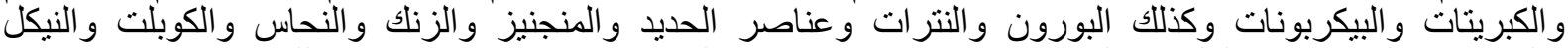

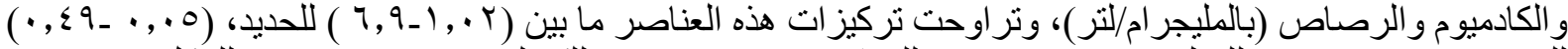

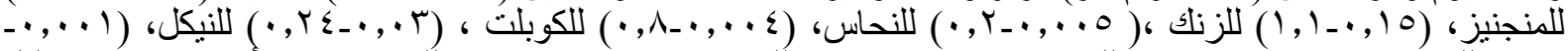

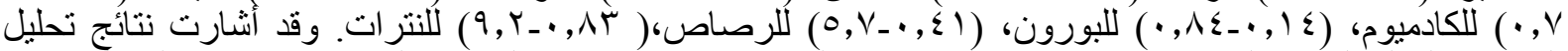

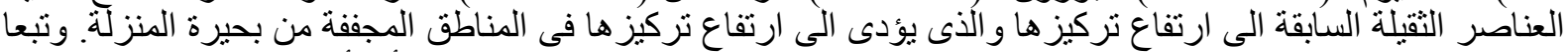

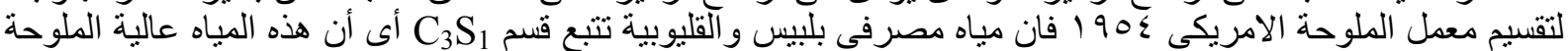

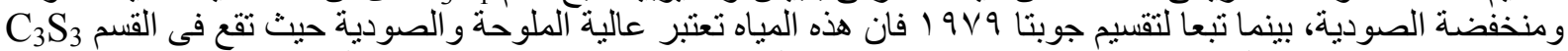

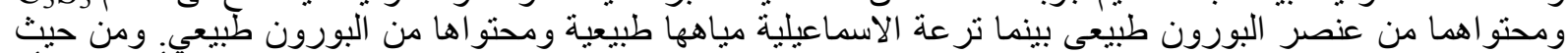

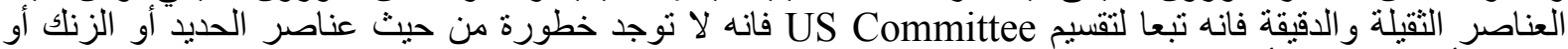

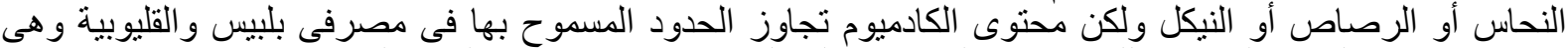

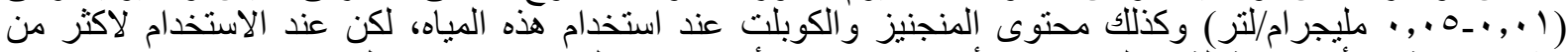
عشرون سنة فى أراضى ثقيلة فهناك تغيير ات أخرى وتقديرات أخرى تم عملها منها تقدير معدل SAR/SCAR. 